\title{
Belgeo
}

Revue belge de géographie

$1 \mid 2021$

Miscellaneous

\section{The Romanian white-collar immigrants in Brussels: a transnational community under construction}

La migration des classes moyennes roumaines à Bruxelles : une communauté transnationale en construction

Sanda Nicola, Caroline Zickgraf and Serge Schmitz

\section{(2) OpenEdition}

\section{Journals}

Electronic version

URL: https://journals.openedition.org/belgeo/46679

DOI: 10.4000/belgeo.46679

ISSN: 2294-9135

Publisher:

National Committee of Geography of Belgium, Société Royale Belge de Géographie

Electronic reference

Sanda Nicola, Caroline Zickgraf and Serge Schmitz, "The Romanian white-collar immigrants in Brussels: a transnational community under construction", Belgeo [Online], 1 | 2021, Online since 19 April 2021, connection on 23 October 2021. URL: http://journals.openedition.org/belgeo/46679 ; DOI: https://doi.org/10.4000/belgeo.46679

This text was automatically generated on 23 October 2021

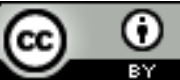

Belgeo est mis à disposition selon les termes de la licence Creative Commons Attribution 4.0 International. 


\title{
The Romanian white-collar immigrants in Brussels: a transnational community under construction
}

\author{
La migration des classes moyennes roumaines à Bruxelles : une communauté \\ transnationale en construction
}

Sanda Nicola, Caroline Zickgraf and Serge Schmitz

\section{Introduction}

1 The Romanian diaspora in Europe grows each year while also becoming more diverse; the profile of the Romanian immigrant differs depending on the region and even the municipality in which you will meet them. In this article, we assess to what extent the Brussels-Capital Region has become one of the favourite destinations for highly qualified Romanian immigrants after the elimination in 2014 of all restrictions imposed on Romanian and Bulgarian citizens in the EU.

2 Two equally important figures underline the need for a deeper understanding of Romanian migration: a) the Eurostat data from 2020 on mobility within the European Union (Fig. 1), indicating that $19.4 \%$ of the Romanian working age citizens are nowadays living in another Member State of the European Union, thus setting a record well above the 3.3\% European average, and b) Statbel data on the resident population in the Brussels-Capital Region (Fig. 2) showing that Romanians are the second largest community of foreigners after the French, also the fastest growing ethnic group in Brussels, having a notably different dynamic from those of the other immigrants arriving from Eastern Europe. 
Figure 1. EU mobile citizens of working age (20-64) by country of citizenship, \% of their homecountry resident population.

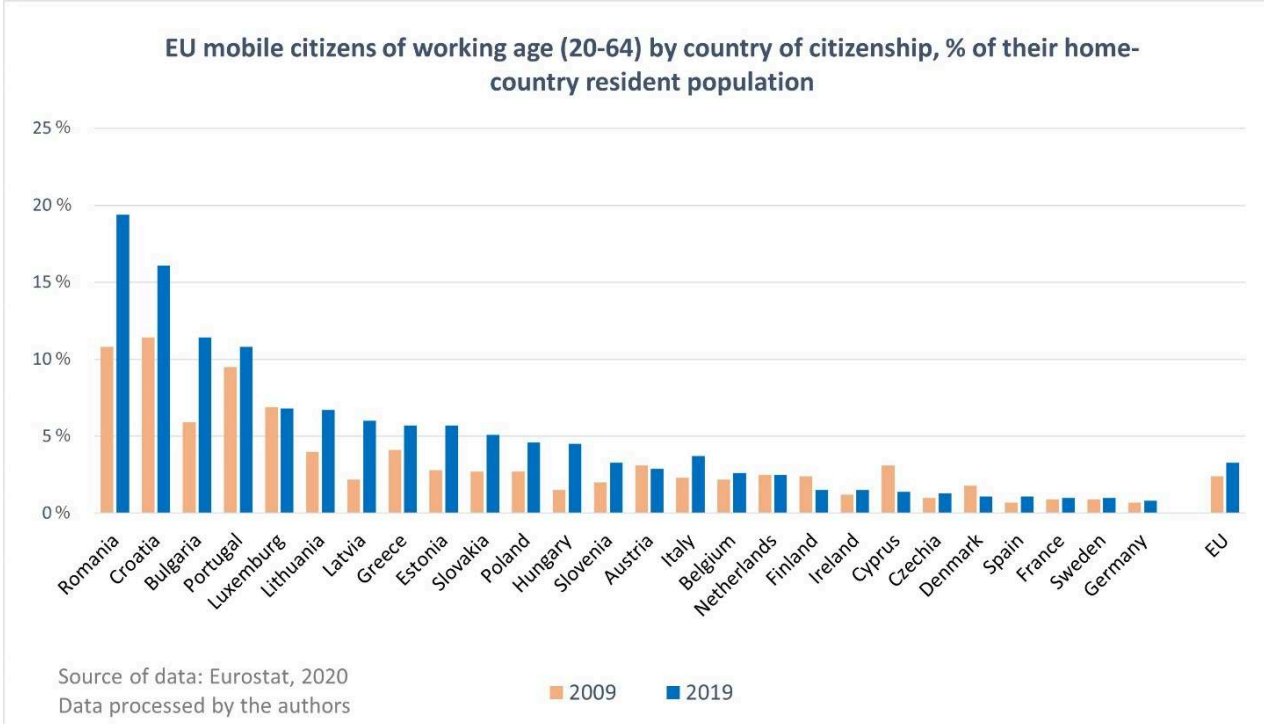

Figure 2. Dynamics of the main communities of foreigners ${ }^{1}$ in BCR from 2000 to 2020.

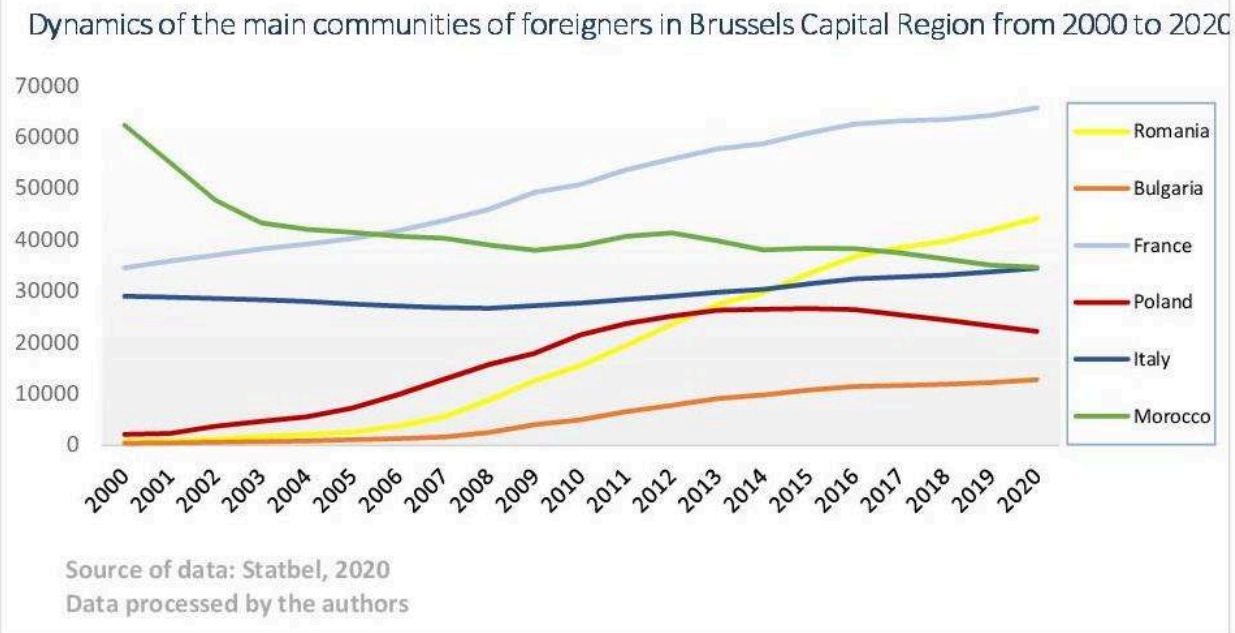

Romanian citizens of working age residing abroad within the EU accounted for about a fifth of the population residing in Romania, making them by far the largest national group among EU mobile citizens. In absolute numbers, the most numerous national groups of mobile EU citizens aged 20-64 were those from Romania (2,280,000 persons), Poland (1,079,000 persons), Italy (965,500 persons) and Portugal (655,600 persons) (Eurostat, 2020).

Sandu et al. (2018, p. 1) underline, on the base of a large survey in different European countries, the "nexus of motivation-experience in the migration process of young Romanians". If job opportunities abroad and precarious employment at home are the first explanation, the authors pointed out the great diversity in the motivations including family and friends, healthcare, and lifestyle reasons. These last reasons are 
usually associated with higher economic development countries, which is not the case of Romania.

5 From 2009 to 2019, the number of those with tertiary educational attainment increased among Romanian mobile citizens from $12.5 \%$ to $15 \%$ (Eurostat, 2020). Romania is the Member State with the lowest percentage of tertiary education graduates among the working age population at $17.5 \%$, while the European Union average is $30.2 \%$. Faced with a shortage of highly qualified staff, Romania's employment rate for people with higher education is $88.4 \%$, i.e., $3.6 \mathrm{pp}$ above the EU27 average and $5.0 \mathrm{pp}$ above the level of employability among mobile Romanian citizens with the same level of training (Eurostat, 2020).

6 Correlating the above statistical data, we deduce that, unlike the low-skilled Romanian workers who often had to emigrate to have a job, those with tertiary education find career opportunities in Romania quite easily, therefore this reasoning elicited the following questions:

-What pushes Romanian white-collar immigrants out of their country of origin and what pulls them towards Brussels-Capital Region?

- Is it all about money?

7 In this article, we define white-collar immigrants as graduated migrants who perform desk, managerial or administrative work and belong to the middle or upper classes. Further in this article we will call them Romanian white-collar immigrants - RWCIs. Our contribution to the research on Romanian migration is that, by delivering the case study on RWCIs in BCR, we signal the emergence of a new wave of immigrants coming from Romania with different features, more diverse motivations, and unique integration strategies.

8 After reviewing recent Romanian migration history, the paper introduces the concepts of Homo Europaeus, Subjective Wellbeing and Sense of Place and then details the mixed-method research methodology. The results section first points out the factors reported during the interviews that explain the increase in the presence of Romanian people in Brussels, secondly, scrutinizes the push and pull factors for RWCIs, and, finally, analyses the complex sense of place and subjective well-being of this emerging transnational community.

\section{Background}

9 The migratory flows from Romania to Western Europe were determined by three political events with historical dimensions, thus the stratification of Romanian immigrants in distinct waves is a prerequisite for a deeper exploration of their dynamics.

December 1989: The end of communist dictatorship ${ }^{2}$ triggers a first wave of emigrants leaving in the early 1990s when Romania opens its borders and Romanian citizens are granted the right to have a permanent passport. This migration wave is formed mainly of low-skilled workers.

11 January 2007: Romania joins the European Union, and this triggers the second wave of emigrants from Romania, much wider and more diverse in terms of professional categories but dominated by medical staff (Séchet, Vasilcu, 2015). The OECD claims that 
since joining the European Union, Romania has lost around 39,000 nurses and over 20,000 doctors who now live and practice abroad (OECD, 2019).

January 2014: All the restrictions imposed on Romanians on the labour market by nine other EU member states - Belgium included - are lifted. It begins the movement to the "West" of a population motivated to obtain a lifestyle still inaccessible in Romania. This is the $3^{\text {rd }}$ wave of Romanian immigrants, made up of those who meet the definition of Homo Europaeus in terms of education and professional skills.

Referring to the Romanian migration to the Brussels-Capital Region in particular, this division into temporal stages does not mean that when a new wave forms, the others have ceased. On the contrary, the three waves intertwine and interact, while exhibiting different features and behaviour within the Romanian community in the host country, and employing new integration strategies (Meeus, 2013). Low-skilled workers continue to come from Romania to Brussels, which proves the continuation of historical waves (Hermia, 2015). Therefore, 2014 is the milestone marking the accelerated arrival of RWCIs to capitalize on the fact that the Belgian labour market is now fully accessible to them (Fic et al., 2016). Moreover, the paper wants to highlight the limited but synergistic relationship between RWCIs and those who emigrated before them, stating that the blanket of low-skilled Romanian workers represents the foundation on which large "transnational communities" ${ }^{3}$ were later built, in countries such as Italy, Spain, Great Britain, Germany, France and, more recently, Belgium. Over this first solid layer of builders, agricultural workers and housekeepers, Romanians from middle and uppermiddle class found the right conditions to settle down and prosper. In this regard, the Romanian community in the Brussels-Capital Region is an optimal case study to illustrate this stratification, as will be demonstrated when we will analyse the factors leading to the accelerated growth of the community.

\section{Theoretical concepts}

\section{Homo Europaeus}

Of all the rights and freedoms arising from membership in the European Union, the freedom to move and reside in any other member state is, arguably, the most valuable advantage (EPRS, 2013). Whether you look at European citizenship only as a "supplement to national citizenship and a practical necessity", as expressed by one of Adrian Favell's characters in his book "Eurostars and eurocities", or on the contrary, an opportunity to break away from a country where you cannot reach your potential and the desired lifestyle, as is the case with the participants in this study, freedom of movement in such a vast, integrated space is one of the greatest blessings of the Maastricht treaty (Favell, 2010). The individual who knows how to make use of all the civil rights offered by European citizenship gains access to new lifestyles, opportunities for personal development, immersion in other cultures and will embody the archetype of the European Man (Homo Europaeus). They will borrow habits from the new places and their identity will be shaped by the new cultural experiences and thus, stripped of their national clothes, the ethnic or social characteristics, this Homo Europaeus would no longer have anything to do with the traditional figure of the migrant (Duez, 2015).

European citizenship has been considered transnational from the outset, derived from the right to live freely in any other EU state, while several civil rights further derived 
from European citizenship. Homo Europaeus has the right to vote, to stand as a candidate or to be elected to the public office in the host country and has been socially identified by Duez (2015) with the following characteristics: European cosmopolitan, polyglot, dynamic, often young, having an important social status, and a graduate of higher education. This citizen belongs to the upper middle class and knows how to take advantage of the opportunities offered by an integrated Europe. They behave as a "talent" aware of their value and move freely in a "knowledge economy" praised by the Lisbon European Council in March 2000. This citizen also represents the archetype of the (neo-) liberal man who would successfully fulfil a job at the European institutions due to its mobility, dynamism, and personal initiative (Duez, 2015). In this article, we do not debate whether there is a European identity and a specific culture adopted in all Member States, but we refer strictly to European citizenship as a determining factor for the emergence of a new pattern of Romanian migration towards Western Europe.

\section{Subjective Well-Being}

This study also aims to explain the aspiration of RWCIs to depart the places where they were born and raised. There are multiple reasons leading people to migrate but most of them expect to improve their lives in one way or another. They migrate to take advantage of the opportunities available elsewhere, imagining that this will bring them benefits including more self-esteem, a higher standard of living and/or a greater worklife balance. Nowok et al. (2013) wrote about this expectation of the immigrant to be happy once they settle in a new place and about "subjective well-being" (SWB), stressing the importance of well-being in the progress of a society. Their study reveals that almost always one's migration is preceded by a period of decline in the happiness of the individual. Questioning the reasons why the Romanian middle class were unhappy in their homeland and why they choose to move to Brussels to start over, the hypothesis emerged that this migratory wave is also caused by severe dysfunctions in the territorial development of post-socialist cities. The idea is supported by the analysis of the chaotic evolution of the real estate sector in Romania and the (non-) regulation of property and pre-emption rights. In theories on international migration with a strong spatial component, aspects related to regional development with an impact on quality of life are considered as crucial variables influencing the international mobility of youth. Exploring an interregional stream, Yang et al. (2015) took several economic variables (regional GDP, income, employment opportunities, investments) combined them with variables related to quality of life (green spaces, investments in education, availability of leisure services and of household facilities) and geographical variables (distances travelled between regions, between home and work/school, etc.) Their study revealed that regional GDP is much less relevant in explaining migration rates than environmental and social indicators that affect the quality of life (Staniscia, Benassi, 2018).

\section{Sense of place}

Given that level of territorial development was identified both as a "push" and a "pull" factor on the Bucharest-Brussels migratory corridor, we reflected on the notion of sense of place, both in relation to the place of birth and the current place of residence. This willingness to break away from their native country and to 'start over' elsewhere, 
which we find clearly manifested in all social strata in Romania, RWCIs included, can be explained by analysing how sense of place is formed. Shmuel Shamaï $(1991,2004)$ points out that this concept cannot be precisely defined but the researcher provides us with a scale as a measuring instrument. Shamaï argues for the importance of measurements by citing Lewis (1979) in that the sense of place is better reflected in human behaviour than by fitting a description of the term, and Relph (1976) who argued for the definition of the concept "by examining the links between place and the phenomenological foundations of geography". Schmitz (2012) quoting Shmuel Shamaï (1991) suggests a structuring of the concept in three distinct stages:

Table 1. Stages of attachment to a place.

\begin{tabular}{|l|l|}
\hline $1^{\text {st }}$ stage & Sense of place begins with an awareness of belonging to the place \\
\hline $2^{\text {nd }}$ stage & Awareness triggers the process of attachment to the place \\
\hline $3^{\text {rd }}$ stage & Attachment leads to the person's commitment to the future of the place \\
\hline
\end{tabular}

Schmitz, 2012

\section{Methodology}

To scrutinize the reasons of RWCIs migration to Brussels, we used mixed-method research design and triangulation of methods (Crang, 1998). This allows to collect information from a broader and more diverse perspectives before collating this information.

\section{Official data and documents}

19 The study is based on a thorough analysis of the data issued in 2020 by Eurostat on mobility and education within $\mathrm{EU}$, and the quantitative data available regarding Romanians in Belgium published by the National Bureau of Statistics of Belgium (Statbel). Relevant statistics for our research were processed in our own productions and correlated with the timing of political decisions taken at national and European levels concerning: 1) the freedom of movement for Romanians; 2) their EU accession; 3) the imposition and suspension of restrictions on the labour market in Belgium. Other official documents were consulted during the research: 2020 European Commission HR Key Figures report on staff members by nationality; 2018 Annual HR report of the European Parliament, Directorate-General for Personnel; Facts and figures on the beginning of the 2019-2020 school year in the European Schools.

\section{The total immersion of the first author in the RWCls lifestyle}

The first author is an RWCI in her 40s who moved from Bucharest to Brussels in 2019 with the entire family, therefore she has accessed herself the benefits derived from European citizenship available for a polyglot Romanian with higher education and a desire to fit in. The marital status and the composition of the household (married to a 
European civil servant, the mother of a child) allowed her to live and report first-hand the complete experience of a Romanian family settling in Brussels. Their own social integration process, linked to the testimonies of other residents she interviewed, contribute to a deeper understanding of why Brussels may be a more convenient destination for RWCIs than other European cities.

Between September 2019 and March 2020, she met and observed in their professional environments or at socio-cultural events over a hundred Romanian residents, from all social categories, this giving her an overview of the entire Romanian community in $B C R$. Through this vast process of documentation, the author was able to observe the dynamics of the Romanian community in Brussels, to evaluate the strengthen of the support networks between immigrants coming from all migratory flows, and to identify in which circumstances they interact and when they choose to distance themselves from each other. Based on the field observations, the questions for the online survey and the guide for the semi-structured interviews were further developed.

\section{Online survey}

A Google Forms Survey was active from April to May 2020, the call asking respondents to have Romanian citizenship and official residence in BCR, without limiting participation according to other criteria $(\mathrm{n}=124)$. The survey included twenty questions, both closed and open, addressing topics related to: emigration date, age, marital status, household composition, education, place of origin, professional situation and SWB before and after emigration. Questions were also raised about the integration process in Brussels, access to lifelong learning, education plans for their children, the exercise of the right to vote, as well as projections on the prospect of returning at some point to Romania. Through this method we collected data providing an overview of the reasons why Romanians from all walks of life chose BCR in such large numbers as an emigration destination and on the general trends of integration.

From the total answers, we subsequently filtered the questionnaires of 70 participants, 38 men and 32 women, who corresponded to the RWCI profile resident in Brussels. In this sample, $53 \%$ of respondents were married or in a stable relationship at the time of emigration, while $46 \%$ were single. $57 \%$ of those surveyed came to Brussels before the age of $30,26 \%$ between the ages of 30 and 40 , and $17 \%$ moved to the Belgian capital after the age of 40. Diagrams were generated to illustrate the traits of this specific population and to see if there are noticeable differences in their perceptions and intentions compared to general community trends.

The infographics contained in this article exclusively reflect the answers collected from subjects with RWCI profile; they cannot be extrapolated to the entire Romanian community in BCR.

\section{Semi-structured interviews}

In this stage, we discussed with fifteen RWCIs about the circumstances in which they decided to emigrate, what were the determining factors for the choice of Brussels and what was their integration strategy. All subjects have Romanian citizenship and residence in Brussels, they have obtained tertiary education and had above average income in Romania prior to emigration. They all had settled in BCR after 2014 and were 
interviewed for this research in April 2020. The recordings have an average duration of 45 minutes and can be the starting point of a longitudinal study. Their profile data can be consulted in Table 2 .

Due to the Covid-19 pandemic declared by the WHO in March 2020 and the lockdown imposed by the Belgian authorities, the initial methodology underwent major adjustments. The semi-structured interviews were conducted online, via a video platform, and the subjects, as well as the survey respondents, were recruited following a call for participation launched on Facebook. Sanitary restrictions and the deadline of the research made it difficult to achieve a balanced gender sampling for one-on-one interviews.

Table 2. Profile data of the participants.

\begin{tabular}{|c|c|c|c|c|c|c|c|c|}
\hline Initials & Age & Gender & Profession & $\begin{array}{l}\text { Marital } \\
\text { status }\end{array}$ & $\begin{array}{l}\text { Place of } \\
\text { birth }\end{array}$ & $\begin{array}{l}\text { Place of } \\
\text { residence } \\
\text { before } \\
\text { Brussels }\end{array}$ & $\begin{array}{l}\text { Year } \\
\text { of } \\
\text { arrival }\end{array}$ & $\begin{array}{l}\text { Commune of } \\
\text { residence in } \\
\text { Brussels }\end{array}$ \\
\hline R.F. & 40 & $F$ & $\begin{array}{l}\text { Business } \\
\text { analyst }\end{array}$ & $\begin{array}{l}\text { Married, } \\
\text { with } \\
\text { children }\end{array}$ & Bucharest & Bucharest & 2019 & $\begin{array}{l}\text { Woluwe } \\
\text { Saint-Pierre }\end{array}$ \\
\hline R.D. & 28 & $\mathrm{~F}$ & Accountant & Single & Bucharest & Bucharest & 2016 & Schaerbeeck \\
\hline A.T. & 33 & $\mathrm{~F}$ & Economist & Married & Bucharest & Bucharest & 2017 & Ixelles \\
\hline M.B. & 28 & $F$ & $\begin{array}{l}\text { Corporate } \\
\text { affairs } \\
\text { manager }\end{array}$ & Single & Bucharest & $\begin{array}{l}\text { Glasgow, } \\
\text { Scotland }\end{array}$ & 2019 & $\begin{array}{l}\text { Woluwe } \\
\text { Saint-Pierre }\end{array}$ \\
\hline D.W. & 44 & $\mathrm{~F}$ & Economist & Single & Bucharest & Bucharest & 2015 & Auderghem \\
\hline D.C. & 45 & $\mathrm{~F}$ & Engineer & $\begin{array}{l}\text { Married, } \\
\text { with } \\
\text { children }\end{array}$ & Bucharest & $\begin{array}{l}\text { Bucharest, } \\
\text { Romania }\end{array}$ & 2019 & $\begin{array}{l}\text { Woluwe } \\
\text { Saint } \\
\text { Lambert }\end{array}$ \\
\hline C.C. & 46 & M & $\begin{array}{l}\text { Software } \\
\text { Engineer }\end{array}$ & $\begin{array}{l}\text { Married, } \\
\text { with } \\
\text { children }\end{array}$ & Bucharest & $\begin{array}{l}\text { Oslo, } \\
\text { Norway }\end{array}$ & 2018 & $\begin{array}{l}\text { Woluwe } \\
\text { Saint- } \\
\text { Lambert }\end{array}$ \\
\hline D.Ci. & 34 & $\mathrm{~F}$ & $\begin{array}{l}\text { Director of } \\
\text { Government } \\
\text { Affairs }\end{array}$ & Single & Sibiu & Bucharest & 2014 & Ixelles \\
\hline A.T. & 32 & $F$ & Doctor & Married & Bucharest & Bucharest & 2019 & $\begin{array}{l}\text { Woluwe } \\
\text { Saint } \\
\text { Lambert }\end{array}$ \\
\hline I.N. & 30 & $\mathrm{~F}$ & Architect & Married & Bucharest & Bucharest & 2015 & Saint-Gilles \\
\hline C.R. & 33 & $\mathrm{~F}$ & Doctor & Married & Buzău & Bucharest & 2015 & Uccle \\
\hline
\end{tabular}




\begin{tabular}{|l|l|l|l|l|l|l|l|l|}
\hline R.D. & 61 & M & Engineer & $\begin{array}{l}\text { Married, } \\
\text { with } \\
\text { children }\end{array}$ & Satu-Mare & Timișoara & 2014 & $\begin{array}{l}\text { Woluwe - } \\
\text { Saint } \\
\text { Lambert }\end{array}$ \\
\hline E.P. & 42 & F & Teacher & $\begin{array}{l}\text { Married, } \\
\text { with } \\
\text { children }\end{array}$ & $\begin{array}{l}\text { Deva, } \\
\text { Hunedoara }\end{array}$ & Bucharest & 2019 & $\begin{array}{l}\text { Woluwe } \\
\text { Saint } \\
\text { Lambert }\end{array}$ \\
\hline C.R. & 40 & M & $\begin{array}{l}\text { Construction } \\
\text { contractor }\end{array}$ & $\begin{array}{l}\text { Married, } \\
\text { with } \\
\text { children }\end{array}$ & $\begin{array}{l}\text { Craiova, } \\
\text { Dolj }\end{array}$ & Craiova & 2014 & Evere \\
\hline S.G. & 50 & F & $\begin{array}{l}\text { Hotel } \\
\text { manager }\end{array}$ & Married & $\begin{array}{l}\text { Piatra } \\
\text { NeamȚ }\end{array}$ & Rome, Italy & 2015 & $\begin{array}{l}\text { Watermael- } \\
\text { Boitsfort }\end{array}$ \\
\hline
\end{tabular}

The sample is composed of more women (12) than men (3), that three out of five are born in Bucharest, that one out of five lived in another European city before coming to Brussels, and that most of them live in the municipalities located in the east of BCR.

In the first part of the interviews, the questions revolved primarily around preemigration lifestyles, career paths, income, and property, to determine why they were dissatisfied with their level of SWB in the country of origin. Another set of questions referred to how the RWCIs planned their move to another country, the criteria for choosing Brussels, and their current lifestyle, to analyse if/how their level of SWB had changed after emigration.

29 A list of specific questions aimed at verifying whether the respondents correspond to the Homo Europaeus archetype described in European Commission documents and the scientific literature. All interviews were conducted in Romanian, with the clear intention of operating with all the subtleties of the mother tongue. The tone of voice and vocabulary used provided additional elements for interpreting the data.

We then aimed to correlate the feelings expressed towards the place of immigration with the indicators provided by Shamaî's Scale to establish to what extent RWCIs have developed attachments to BCR. The use of the Shamaï scale (1991) in the form adapted by Schmitz (2012) was essential in the debate about factors shaping the migratory corridor from Bucharest to Brussels. This represents a turning point in our research, feeding the debate with new perspectives and revealing the necessity for an adaptation of the scale (Annex 1).

\section{Results}

31 According to the Belgian National Bureau of Statistics, at the beginning of 2020 the number of Romanian citizens with residence documents in the Brussels-Capital Region was 44,129 . We may assume that the Romanian presence in BCR is, in fact, greater because these statistics do not include those who have dual citizenship ${ }^{4}$, both Romanian and Belgian. It should also be mentioned that the European Union legislation requires you to register with the municipality as a resident only if the uninterrupted stay exceeds three months. There are professions and types of contracts allowing the worker, in constructions for instance, to come for a project of a few weeks on a 
construction site, where the contractor often offers accommodation and meals, and if the stay does not exceed three months, they have no obligation to register. There are many Romanians who travel several times a year between Romania and Belgium, who maybe spend more time in Brussels than at home, but who are not included in any official database. However, with 44,129 residents officially registered, Romanians are today the second largest community of foreigners in Brussels-Capital Region, after the French $(65,656)$. The number of Romanian citizens holding residence documents in Brussels-Capital Region (BCR) is higher today than the number of Moroccan $(34,597)$ and Italian residents $(34,422)$, ethnic groups with a long tradition of immigration in Belgium, although this, too, may be impacted by the acquisition of citizenship among the latter groups.

\section{Factors that favoured the accelerated growth of the Romanian community in Brussels-Capital Region between 2000 and 2020}

Besides the predictable elements that led to the widening of the Romania-Belgium migration corridor, such as the accession to the EU, in 2007 and the elimination of all the restrictions imposed on Romanians on the labour market in 2014, the interviews highlighted several elements that can be overlooked if one focuses exclusively on statistics and less on in-depth, qualitative understandings.

\section{Global economic factors}

Both the interviews and the literature point out that a key moment leading to the intensification of Romanian migration to Belgium was the economic crisis of 2008-2010 that affected the real estate sector and severely disrupted activity on construction sites across Europe, with one exception: Poland. When countries such as Italy, Spain or Portugal entered a recession, Poland's economy grew, and many Polish workers on construction sites in Western Europe received generous job offers in their country of origin (Kaczmarczyk et al., 2016). In the newly created context, some Polish workers in Belgium decided to return home amid economic growth, others became engaged in a circular movement between the two countries, while Romanians were coming in large numbers, on three distinct channels: from Romania, from Italy and from Spain (Ciobanu, 2015). According to construction contractors in Belgium at that time, many of the jobs vacated by the Poles were occupied by Romanians coming from the countries of Southern Europe. C.R., a Romanian entrepreneur based in Brussels reported that Romanian is now the most spoken language on construction sites in Belgium and he supported his statement with a test he did for us. The Belgian state assigns a code to each site, and each worker has a card, being obliged to check-in when he arrives at work. Both the state and entrepreneurs can find out at any time who is on a certain site. C.R. introduced the codes of the projects for which his company builds roofs and listed who was there at that moment. Between 30 and $40 \%$ of the workers on all the verified sites were Romanians. The program does not show their nationality, but names such as Ion, Vasile, Marin or Popescu suggest Romanian background. 


\section{Elimination of transitional restrictions on the Belgian labour market}

When restrictions imposed on Romanians on the labour market were lifted in 2014, Belgium became an attractive destination for people who were considering emigration but were undecided where to settle. Brussels, due to the presence of European institutions and other international bodies or large multinational companies, offered the prospect of a career for many Romanians with higher education. A.T. and her husband had good careers in Bucharest, yet they wanted a different lifestyle, therefore they designed a plan to move to Brussels:

"In 2013, we were both interns at the European Commission. We tasted a little of life in Brussels, we saw the difference and fell in love with the city. We would have stayed then, but it was not a favourable context. However, we decided that if at some point an opportunity arises, at least for one of us, then we will leave Romania. We returned to Bucharest but immediately started actively looking for jobs in Brussels."

A.T. female, 33, economist

\section{The principle of geographical balance in the European institutions}

As a rule, discrimination on grounds of nationality is prohibited by the EU Treaties, the Charter of Fundamental Rights, and the Staff Regulations. The latter requires the EU institutions to recruit staff from the widest possible geographical base. In a situation "where the qualifications of the different applicants are substantially the same", the regulation allows the criterion of geographical balance to prevail ${ }^{5}$. This issue was raised as the Union expanded to new Member States, aiming to achieve within a limited time frame an adequate level of representation of the citizens of the new Member States. To harmonize the share of Member States, guiding rates ${ }^{6}$ were introduced in 2003 to equitably balance the need to reflect the composition of the EU population and, at the same time, to ensure a minimum representation of smaller Member States. The guiding rate for Romania is $4.5 \%$, and according to a 2020 human resources report, the employability target for Romanian citizens at the European Commission has almost been reached. Out of the total of 32,847 employees, $4.2 \%$ are Romanian citizens (Fig. 3).

Figure 3. Staff members of the European Commission by nationality in 2020.

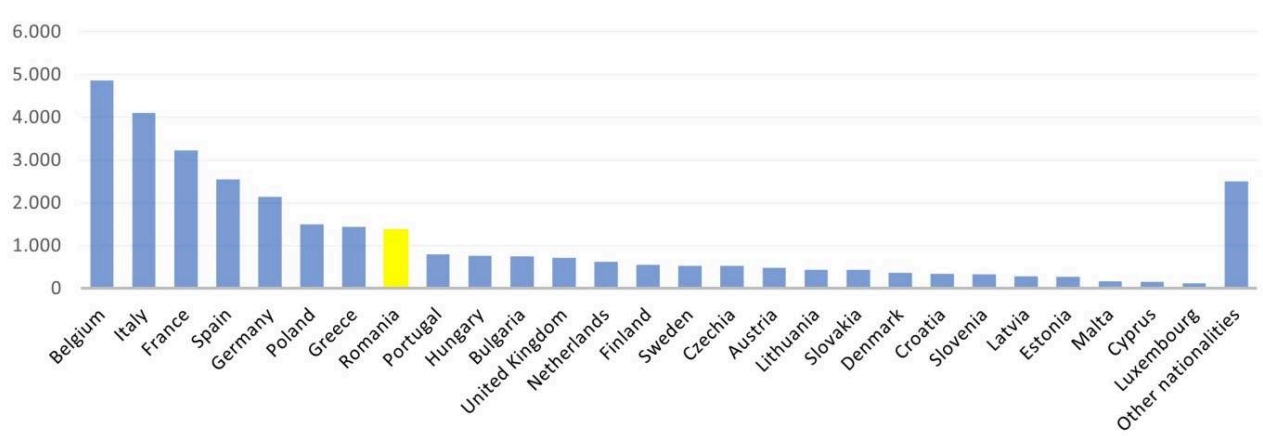


In the European Parliament, the share of Romanians is even higher than in the European Commission, reaching $4.6 \%$ in $2018^{7}$. From 2008 to 2018, the number of Romanian civil servants increased by $136.8 \%$. The annual report on human resources of the European Parliament from 2018 showed that $65.4 \%$ of the total staff of Romanian citizenship are women, and the average age of Romanian employees is 40 .

In the absence of previous studies on the education of Romanian immigrants in BCR, the growing number of Romanians working in European institutions, where the basic criterion for entry is to have a bachelor's degree and speak two of the official languages in the EU, seems to confirm our thesis that BCR is the pole of attraction for RWCIs. Another confirmation was hidden in the centralization of applications submitted during 2010-2017 ${ }^{8}$ by Romanian citizens for EPSO (European Personnel Selection Office) competitions. Leaving aside the low success rate of only $0.4 \%$, we note that 25,933 Romanians entered competitions for a European civil servant position. Romanians are surpassed in this respect only by Italians, with 49,325 applications in the same period, and Spaniards, with 27,569 applications submitted.

\section{Linguistic factors in business communication}

French can be an attractive language due to its linguistic proximity to Romanian, but several respondents emphasized the benefits of learning Dutch. As Flanders covers $44.5 \%$ of Belgium's territory and accounts for most of the country's industry and labour, the region providing 59.2\% of the country's gross domestic product (Eurostat, 2019), several Romanian contractors have learned Dutch, consolidating working relations in this region. This effort of cultural integration resulted in economic benefits: more contracts and, implicitly, the need for even more Romanian workers. On the other hand, when local entrepreneurs reached the conclusion that Romanian workers became indispensable for their business, they considered it profitable to also recruit Romanian management to overcome the language barrier in communicating with workers. Therefore, jobs have been created for highly qualified Romanians as well.

R.D., for example, is a graduate of the Academy of Economic Sciences in Bucharest, following a section where the courses are held in French. When she decided to emigrate, she considered only the francophone countries.

"I thought of France first, but I had previously had an ugly student experience there. I felt racism and discrimination in France. Canada could have been a good option, but it is too far away, so I carefully prospected the idea of living in Belgium. In two and a half weeks I got my one-way plane ticket. I found my current job fast, at a Romanian construction company. Beyond my diploma, the great advantage in my CV was that I am a native Romanian speaker, and I can communicate well with the subordinate staff."

R.D, female, 28, accountant

\section{Mobility factors}

There is potentially a cause-and-effect relationship between the increase in the number of Romanians living in Belgium and the increase in the number of flights between the two countries, but the reasoning is also valid in the opposite direction. Once low-cost flights arrived at airports in all the provinces of Romania, Brussels became even more attractive for those who dreamed of a transnational lifestyle that would allow them to integrate into the host country while still maintaining strong ties with the home 
country. In March 2020, there were 28 weekly flights to Romania from Brussels Airport and Charleroi. From these two Belgian airports, there were direct connections with seven airports in all provinces of Romania, operated by four carriers.

D.C. is originally from Sibiu, in the province of Transylvania, but before leaving Romania she lived in Bucharest where she worked for an advertising agency. The bad roads and poor railway infrastructure between Bucharest and Sibiu crossing the Southern Carpathians made a journey to her family last on average five hours.

"It was also very tiring to drive on serpentines, often at night. I kept hoping that a highway would be built. It has not happened yet. I ended up going to see my parents at most three times a year. From Brussels I have a low-cost direct flight and I get to Sibiu in three hours. Before the pandemic, I have really managed to see my family more often than when I lived in Bucharest."

D.C. female, 34 , govt. affairs director

For R.F. the possibility to fly quickly back to Romania in case of a family emergency was also important in choosing Brussels over other destinations.

“My husband would like to go to Canada, but my parents are old, and I can't go that far. Knowing that I can reach them in a few hours weighed heavily in the decision to come here. As long as my parents are alive, we certainly won't go anywhere else."

R.F. female, 40, business analyst

\section{Push and pull factors for the RWCls in BCR.}

The factors mentioned in the above section contributed to the explanation of the growth of Romanian migrants in Brussels. However, RWCI's motivations to move from Romania to Brussels require the analysis of both "push" and "pull" factors and individual pathways. Apart from well-paid jobs, what are the elements that push, attract, and retain RWCIs to Brussels?

Half of the participants in the survey are people over the age of 35 , they have families and children, and they emigrated based on rigorous documentation looking for a place where every family member can feel fulfilled. Listening to their arguments, it is easy to understand why they chose the Belgian capital to start a new life, but the perplexity regarding the factors that triggered their departure from their homeland persists. To get to a more generalisable answer, we analysed a series of individual, subjective experiences. Such an approach required serious reflections on notions such as "middle class", "urban dysfunctions" and "sense of place" in post-communist Romania prior to interpreting statistics. 
Figure 4. Reasons for leaving Romania.

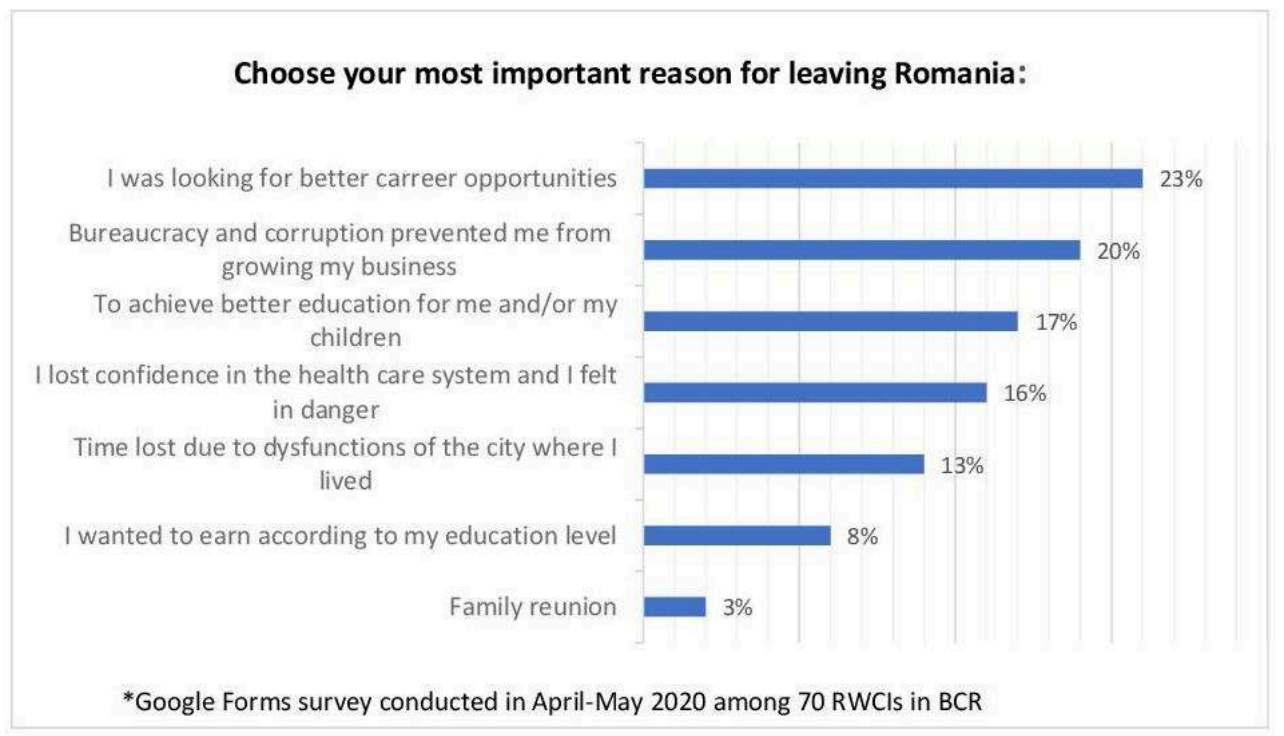

Of those that left Romania out of a desire to seek better career opportunities (23\%), most of them speak with dissatisfaction about the work environment in their home country and the absence of clear objective criteria for advancement. Those who have tried their luck in entrepreneurship (20\%) complain that bureaucracy, accompanied by incompetence and corruption, often made them feel powerless. For those who have families and children, the reasons most often invoked refer to giving their children access to good education and a high-performing healthcare system, while all the immigrants that used to live in Bucharest mention the stress and anxiety accumulated while being stuck in traffic and the impossibility to adopt a more nature-friendly lifestyle.

"Our daughter had a terribly busy schedule in Romania, and we were in a continuous race. At noon she had to be taken from school to after-school and later to a club where she takes dance classes. Since public transportation was not an option due to bad connections and big delays, we all had to leave by car at 7.30 in the morning and the three of us would return home at 21.00. Having no other choice but to run out of work so I could take the girl from school to the other places where she had activities, I was constantly stressed that we would not arrive on time or that my absence would be noticed at work and I will get fired. In the evening I was so exhausted, I could not even cook dinner. No one can live like this forever." D.C, female, 40 , engineer

The problem of the dysfunctional traffic in Bucharest and other big cities, as well as housing challenges, originate in the territorial development strategy during the communist regime (Alpopi et al., 2014; Hlaváček et al., 2016). Thirty years after the fall of communism, few of Romania's cities have undergone urban regeneration processes to adapt the network of streets, blocks of flats, parking lots and green spaces to the needs of today (Gyongyi, Lazlo, 2008; Cucciolla, 2014). Often, these are old communist neighbourhoods with grey, beehive blocks built to outline a lifestyle. Each tenant could spy on several neighbours, the walls were deliberately thin, so that one could hear what was being said in the neighbouring apartment and inform the political police (Majuru, 2019). People lived in apartments distributed at work, based on a file that assessed the composition of the family but also the activity as a member of the Communist Party, a 
mandatory criterion for career advancement and obtaining a home (Irimie, 2014). The communists built a great deal, with the sole purpose of making functional buildings, but devoid of any architectural or aesthetic value. Comfort was not a concern, the cultural landscape only served as a platform for ideological propaganda that standardized social classes and flattened personalities (Leustean, 2007).

To escape urban chaos and the anxiety they acquired living and working in Bucharest, the citizens from the fragile Romanian middle class pull the last ace up their sleeves: European citizenship. When they decide to emigrate, many will start by setting up an EPSO account and actively looking for jobs in European institutions. As shown in Figure 5 , the possibility of a career as a European civil servant is the main reason why most of the respondents arrived in Brussels.

Figure 5. The most important reasons for settling in Brussels.

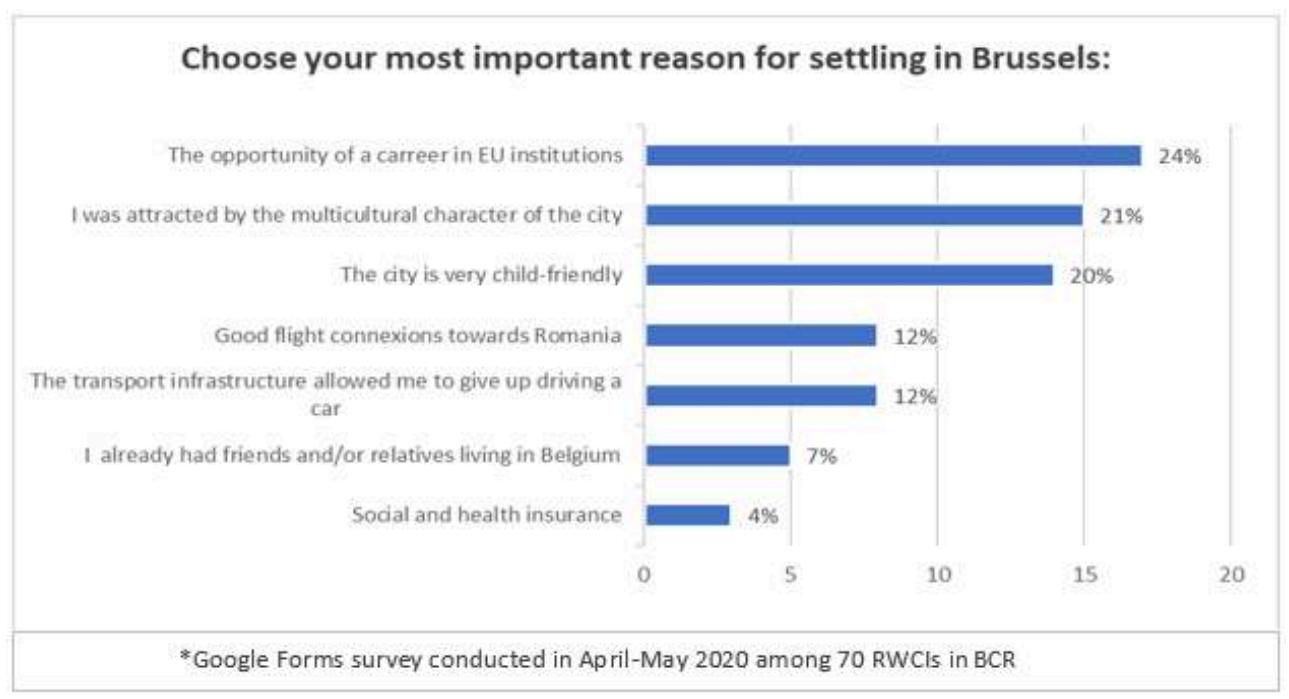

One quarter of survey respondents (Fig. 5) said that the decisive factor for choosing Brussels was the opportunity to work in a European institution. However, this answer does not only talk about the career itself, but of the whole package of privileges that the status of European civil servant implies. By obtaining a full-time contract at the European Commission, the employee knows that they obtain the guarantee of a generous salary, relocation allowances, fixed working hours, VAT deductions, diplomatic discounts on the purchase of certain goods, health insurance with substantial compensations, access for their children to European schools. Therefore, this answer requires a broader interpretation because in most cases it is about the job as well as the attached lifestyle. Another factor that makes Romanian immigrants feel satisfied in Brussels is the multicultural character of the city. In the mixture of 184 nationalities (BISA, 2020) where they have become the second largest community, Romanians feel well anchored. The parks, public transport and the health care system are other strong arguments for them to live in Brussels, but they also often mentioned the politeness and friendly character of the Belgians. 


\section{Sense of place and subjective well-being}

satisfaction: $50 \%$ are very satisfied, $49 \%$ said they are satisfied and only $1 \%$ say they are rather dissatisfied.

"A year after I moved here, it was obvious that my stress level had dropped considerably. In Bucharest I was in a continuous fight and always with the guard up. I had to keep myself away from pickpockets on the bus, not to be cheated by the taxi driver, etc. I found that I no longer worry as much. I do not obsess about the functioning of the state. In Romania I felt that I had to supervise, to know everything that is decided, to know how to protect myself in front of the state."

D.C. female, 34 , govt. affairs director

We then tried to find out if this result tells us how happy RWCIs are in Brussels or how unhappy they were in Romania, or a combination of both. The dilemma arises whether these immigrants have no attachment whatsoever to their places of origin and national identity, or the attachment exists, but it is well hidden under several layers of frustration developed while living unbalanced lives in dysfunctional cities. We have tried to provide the answer to this question by using Shamaï's scale (see Annex). the place of immigration. Taking as a benchmark the six steps described by Schmitz, we could estimate the level of attachment for each of the interviewees. Although they have only settled in Brussels for a few years, all fifteen residents had already passed level 3, which implies a strong emotional involvement and the place to be described as the central scene of important events. When people talk happily about how they moved into a beautiful house like they never had before, about professional successes, graduation ceremonies, the birth of their children and all these life events happened in Brussels, this reflects an emotional attachment. Going even higher on the Shamaï scale, it was revealed to us that most of them are reaching the level 5 of attachment, shown by property investment, and having a long-term school plan for their children in Brussels. Our reasoning could have stopped here, at the portrait of a happy community of Romanians residing in the Belgian capital, but this portrait is not realistic because it does not include dissatisfaction and/or resentment towards the country of origin (Prelipceanu, 2008). These sentiments appeared frequently, even unprovoked, during the one-on-one interviews.

Shamaï refined his own scale in 2005, admitting that the sense of place is not an eminently positive attribute, but there can be negative feelings about a place you are attached to, still he says nothing about the feeling towards one's home country. Shamaï had considered negative feelings of the immigrant exclusively in relation to the place where they immigrated and had not foreseen the situation in which the immigrant lives with resentments towards the place from which they emigrated. In other words, the high appreciation that Romanians have for Brussels is not determined only by an objective outlook upon the socio-economic realities in the Belgium Capital but include the comparison with the realities they have faced in Romania and it is influenced by their expectation to be happier than before migration, suggesting that well-being is subjective and relative. Shamaii's scale may be adapted once again, focusing on how the level of frustration felt in the origin country influences the process of attachment to the destination. The population in this study experiences the frustration of being prevented from reaching their true potential in their country of origin and are driven 
by their ambition to integrate in the host country (Meeus, 2013). The resentment felt in relation to the country of origin and the ambition to succeed among foreigners, these are the triggers that gave birth to a form of high resilience noticed in many Romanian immigrants residing in Brussels. These findings are in accordance with the results of the studies conducted by Trandafiroiu (2013), stating that precisely this resilience is the main characteristic that helps Romanians to go through structural transformations quite easily, being the most mobile people in Europe (c.f. Eurostat, 2020).

Figure 6. Under what circumstances would you return to live in Romania?

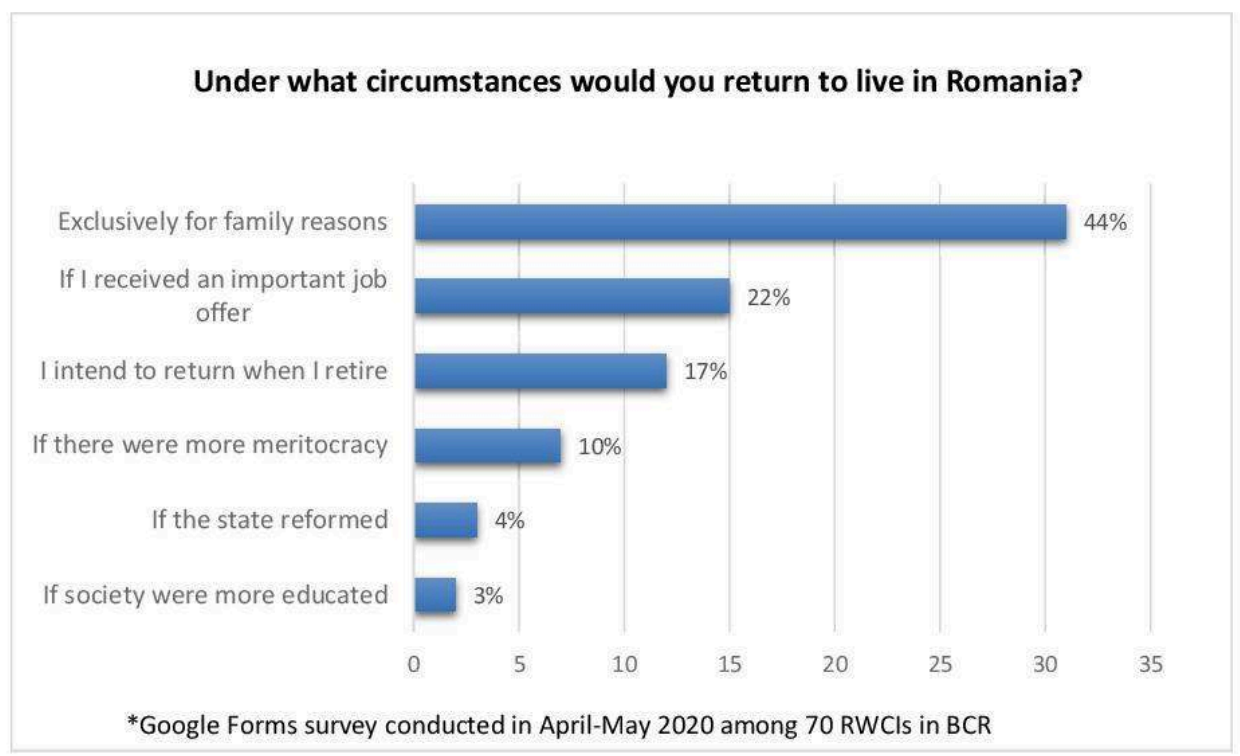

The notable difference between the exponents of this third wave of migrants from Romania compared to the previous two is that the latter are determined to stay in Brussels indefinitely, consequently accessing all cultural levers for a successful integration. They improve their language skills, equate their studies, and even continue them in Belgium, guide their children to acquire both official languages to expand their educational and professional options in the future. The myth of returning is not a concern for them and, as Figure 6 indicates, 44\% of those surveyed would return to live in Romania exclusively for family reasons, while $22 \%$ would consider this option only if they received a particularly important job offer.

Sense of place was a notion tested in the spring of 2020 when the Covid-19 pandemic was declared. As Witchalls (2020) estimates, "COVID-19 fundamentally disturbs the feeling of place. This is causing transformational changes in cities around the world. The daily parts of city life, such as commonplaces, crowded trains, and food outside, have suddenly become threatening". In the face of an unseen adversary, people reconsidered their sense of place based on the feeling of health security but also the feeling of freedom that people in cities around the world could experience under the circumstances of a drastically limited freedom of movement. Romanian citizenship would have allowed the subjects interviewed to repatriate when they saw how fast the infection rate and the death toll on Belgium were increasing. That is why we added to the Google survey some questions regarding the decision to leave or to stay in Belgium. The results presented in the figures below force us once again to reflect on whether they speak of attachment to Brussels or fears about Romania. However, more research 
is needed to draw a relevant conclusion. Facing a health threat, when they questioned whether they should stay in Belgium or go back to Romania to be close to their relatives, most of them flatly rejected the idea of returning. More than $80 \%$ of respondents said they did not consider leaving Brussels, despite the much higher number of infections and deaths reported in Belgium compared to Romania.

Figure 7. Why did you prefer to stay isolated in Brussels rather than going back to your home country?

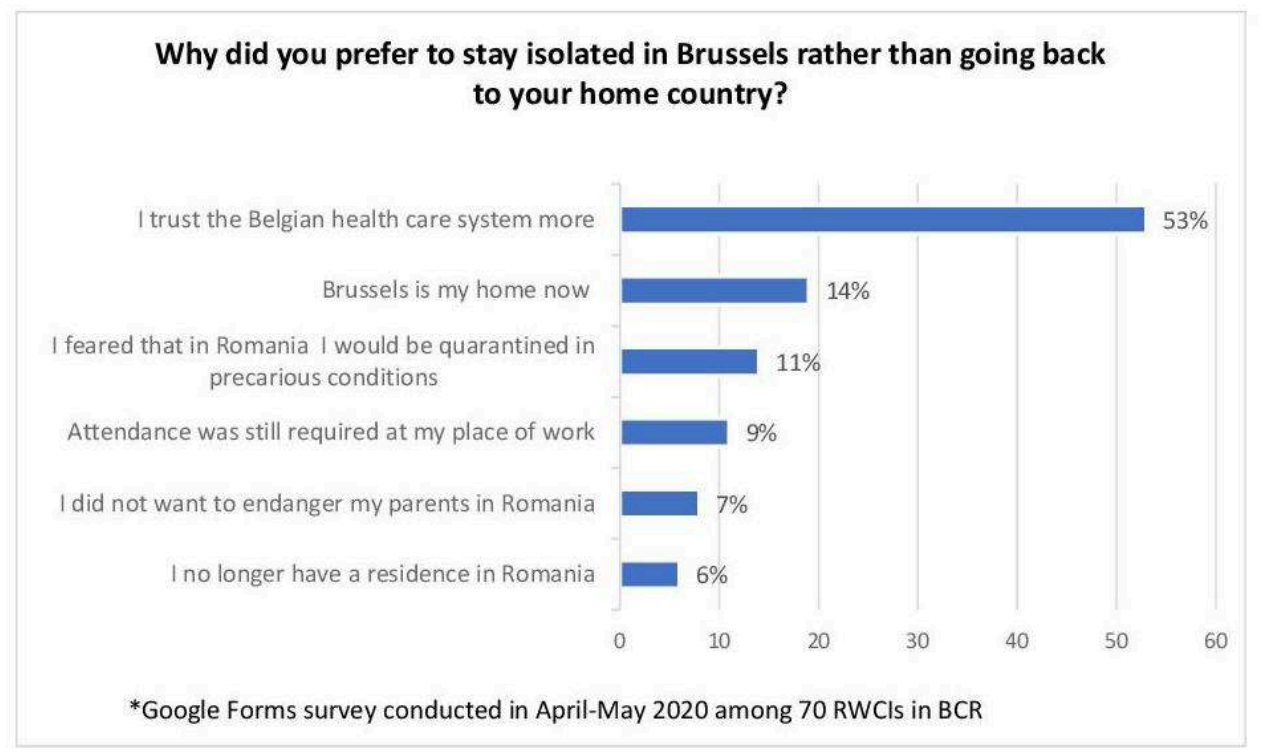

This sanitary crisis has once again revealed the endemic distrust that Romanians have in the authorities in Bucharest and in the public healthcare system. 53\% of those surveyed in April-May 2020 considered that they are better protected in Belgium, while $11 \%$ repressed their desire to go to their families because of expected poor quarantine conditions. While talking to D.W., the worrying situation in the Romanian hospitals with non-performing equipment and with a high deficit of well-trained staff appeared in discussion:

“God, forbid! If I am getting sick and I am going to a hospital in Brussels, I'm sure I'd be well taken care of. The big risk in Romania is to arrive healthy to the hospital and leave sick or even dead."

D.W, female, 44, economist

Finally, as a Homo Europaeus and transnationalist, the RWCI from Brussels is decided to make use of all civil rights and liberties that he/she has, and, for different reasons and interests is willing to participate in the elections in both countries. More than half (56\%) of respondents did not vote in the 2019 local elections in Belgium, many of them considering that they had been in this country for too little time to have an informed opinion about local politics. Less than ten percent (8\%) did not know they had this right, but said they were interested, and they will participate in the future.

Regarding the elections in Romania, RWCIs show a high interest, and 67\% of those surveyed want to exercise their right to vote on every occasion. From the answers to the open question "How important is it to keep your right to vote in your country of origin?" it is understood that the vast majority consider it a right and even an obligation to help their compatriots within the borders by voting ${ }^{9}$. 


\section{Conclusions}

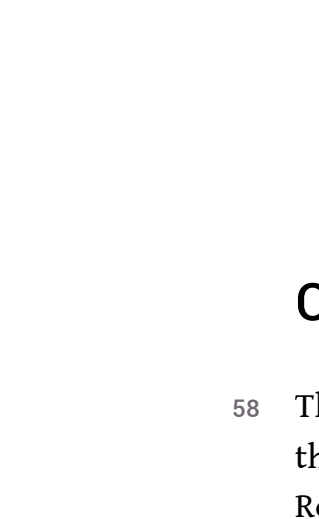
comparison with the first wave of low skilled workers and the second wave dominated
by medical staff during the transition period. This third migratory wave engages
graduate people who are looking for a better lifestyle that goes beyond a well-paid job.
They appreciate the possibilities given by the Brussels-Capital Region, perceived to be a
much better place than the Romanian cities in terms of public services. Although
beyond the scope of the current study, it would be worthwhile to analyse the impact of
such a group in the different municipalities in which they live. How do they interact
with previous waves of Romanian migrants and contribute to the economic and social The presented research aimed to analyse a new kind of Romanian migrants to Belgium,
those who arrived after the removal of transitional restrictions for Bulgarians and comparison with the first wave of low skilled workers and the second wave dominated
by medical staff during the transition period. This third migratory wave engages
graduate people who are looking for a better lifestyle that goes beyond a well-paid job.
They appreciate the possibilities given by the Brussels-Capital Region, perceived to be a
much better place than the Romanian cities in terms of public services. Although
beyond the scope of the current study, it would be worthwhile to analyse the impact of
such a group in the different municipalities in which they live. How do they interact
with previous waves of Romanian migrants and contribute to the economic and social comparison with the first wave of low skilled workers and the second wave dominated
by medical staff during the transition period. This third migratory wave engages
graduate people who are looking for a better lifestyle that goes beyond a well-paid job.
They appreciate the possibilities given by the Brussels-Capital Region, perceived to be a
much better place than the Romanian cities in terms of public services. Although
beyond the scope of the current study, it would be worthwhile to analyse the impact of
such a group in the different municipalities in which they live. How do they interact
with previous waves of Romanian migrants and contribute to the economic and social comparison with the first wave of low skilled workers and the second wave dominated
by medical staff during the transition period. This third migratory wave engages
graduate people who are looking for a better lifestyle that goes beyond a well-paid job.
They appreciate the possibilities given by the Brussels-Capital Region, perceived to be a
much better place than the Romanian cities in terms of public services. Although
beyond the scope of the current study, it would be worthwhile to analyse the impact of
such a group in the different municipalities in which they live. How do they interact
with previous waves of Romanian migrants and contribute to the economic and social comparison with the first wave of low skilled workers and the second wave dominated
by medical staff during the transition period. This third migratory wave engages
graduate people who are looking for a better lifestyle that goes beyond a well-paid job.
They appreciate the possibilities given by the Brussels-Capital Region, perceived to be a
much better place than the Romanian cities in terms of public services. Although
beyond the scope of the current study, it would be worthwhile to analyse the impact of
such a group in the different municipalities in which they live. How do they interact
with previous waves of Romanian migrants and contribute to the economic and social comparison with the first wave of low skilled workers and the second wave dominated
by medical staff during the transition period. This third migratory wave engages
graduate people who are looking for a better lifestyle that goes beyond a well-paid job.
They appreciate the possibilities given by the Brussels-Capital Region, perceived to be a
much better place than the Romanian cities in terms of public services. Although
beyond the scope of the current study, it would be worthwhile to analyse the impact of
such a group in the different municipalities in which they live. How do they interact
with previous waves of Romanian migrants and contribute to the economic and social comparison with the first wave of low skilled workers and the second wave dominated
by medical staff during the transition period. This third migratory wave engages
graduate people who are looking for a better lifestyle that goes beyond a well-paid job.
They appreciate the possibilities given by the Brussels-Capital Region, perceived to be a
much better place than the Romanian cities in terms of public services. Although
beyond the scope of the current study, it would be worthwhile to analyse the impact of
such a group in the different municipalities in which they live. How do they interact
with previous waves of Romanian migrants and contribute to the economic and social comparison with the first wave of low skilled workers and the second wave dominated
by medical staff during the transition period. This third migratory wave engages
graduate people who are looking for a better lifestyle that goes beyond a well-paid job.
They appreciate the possibilities given by the Brussels-Capital Region, perceived to be a
much better place than the Romanian cities in terms of public services. Although
beyond the scope of the current study, it would be worthwhile to analyse the impact of
such a group in the different municipalities in which they live. How do they interact
with previous waves of Romanian migrants and contribute to the economic and social development of their municipalities and influence the local society and culture?

Our research reveals a long list of reasons to move to Brussels, demonstrating the multi-causality of international migration: standard of living, international career, quality of health care and education system, greenery, and leisure options, and, importantly, to achieve a work-life balance that will increase their SWB. Most of these reasons are confirmed by Mocanu et al. (2020) In addition, the presence of many less skilled Romanian workers creates opportunities for Romanian speakers and speakers of one or two of the Belgian national languages. To understand why many RWCIs chose to move to Brussels, it is important to fully understand what causes these people to leave Romania. Negative place attachment and dissatisfaction in Romania in relation to the public sector (administration, hospitals, schools and universities, police, etc.) favoured high out-mobility of Romanians. Romanian respondents in Belgium often perceive the Romanian state as an aggressor, while the Belgian state is seen as a partner that encourages them to evolve and prosper. RWCIs reflect a strong sense of place towards the new city of residence, which is stimulated by the difficult living conditions in Romania. By comparing the sense of place in relation to previous and current places of life, the research suggests paying attention to ambivalent feelings about both places.

In practice, migrants do not need to choose a singular national identity, nor are they obliged to sever ties with their country of origin upon arrival in the destination, as demonstrated by the vast literature on transnational communities, identities, and practices (Glick Schiller et al., 1992; Guarnizo, 1997; Hondagneu-Sotelo, Avila, 1997). The multiplication of low-cost flights between Belgium and several cities in Romania attests to the new connections between the two countries and contributes to the quality of life of migrants, who are then able to engage in transnational practices including movement itself between the two countries. They can keep and even strengthen ties with the family in Romania. While most RWCIs want to stay in Belgium indefinitely, the option to move between and within the transnational social space is highly appealing (Faist, 2000). This transnational space contributes to the Homo Europaeus model which praises the mobility of European citizens. Moreover, the RWCIs raise other RWCIs. Given that out of over 105,000 Romanians living in Belgium, just over 16,000 live in Wallonia, the rest being divided almost equally between Flanders and Brussels, it would be worth analysing in further research whether and how Romanians of the second generation integrate into transnational spaces linking Romania and Belgium. 


\section{BIBLIOGRAPHY}

ALPOPI C., IACOBOAEA C. \& STĂNESCU A. (2014), "Analysis of the Current Housing Situation in Romania in the European Context”, Transylvanian Review of Administrative Sciences, 10, 43E, pp. 5-24.

CIOBANU R.O. (2015), “Multiple Migration Flows of Romanians”, Mobilities, 10, 3, pp. 466-85, https://doi.org/10.1080/17450101.2013.863498

CRANG M. (1998), Cultural geography, London, Routledge.

CUCCIOLLA R.M. (2014) “Changing Urban Landscapes. Eastern European and Post-Soviet Cities since 1989”, Europe-Asia Studies, 66, 8, pp. 1386-1388, https://doi.org/

$10.1080 / 09668136.2014 .941698$

CULIC I. (2005), "Re-Writing the History of Romania after the Fall of Communism", History Compass, 3, 1, https://doi.org/10.1111/j.1478-0542.2005.00157.x

DUEZ D. (2015), « Libre circulation, contrôles aux frontières et citoyenneté », Belgeo, 2, https:// doi.org/10.4000/belgeo.16701

EPRS (European Parliament Research Service Library) (2013), Free movement of persons in the EU: how free, under what conditions and for whom?, Brussels, European Parliamentary Research Service, retrieved May 2020 from www.epthinktank.eu

FAIST T. (2000), The Volume and Dynamics of International Migration and Transnational Social Spaces, Oxford, Oxford University Press.

FAVELL A. (2008), Eurostars and Eurocities. Free movement and mobility in an integrating Europe, Blackwell Publishing.

FAVELL A. (2010), “European identity and European citizenship in three 'eurocities': a sociological approach to the European Union", Politique européenne, 30, 1, pp. 187-224, https:// doi.org/10.3917/poeu.030.0187

FIC T., HOLLAND D., PALUCHOWSKI P. \& PORTES J. (2016), “The redistributive impacts of migration after the EU's eastern enlargement", in Labor Migration, EU Enlargement, and the great recession, Springer, Berlin, Heidelberg, pp. 35-57.

GLICK SCHILLER N., BASCH L. \& BLANC-SZANTON C. (1992), “Transnationalism: A New Analytic Framework for Understanding Migration”, Annals of the New York Academy of Sciences, 645, 1, pp. 1-24, https://doi.org/10.1111/j.1749-6632.1992.tb33484.x

GUARNIZO L.E. (1997), “The Emergence of a Transnational Social Formation and The Mirage of Return Migration Among Dominican Transmigrants”, Identities, 4, 2, pp. 281-322, https://doi.org/ 10.1080/1070289x.1997.9962591

GYONGYI P., LASZLO P. (2008), "Urban Housing Problem in Romania: The Legacy of Communist Block of Flats”, Studia Universitatis Babes-Bolyai Sociologia, LIV, 1, pp. 79-100.

HERMIA J.-P. (2015), « Un boom démographique à la loupe : Roumains, Polonais et Bulgares en Région de Bruxelles-Capitale », in Focus de l'IBSA, 9.

HERMIA J.-P., VANDERMOTTEN C. (2015), « Le monde dans Bruxelles, Bruxelles dans le monde », Brussels Studies, 94, https://doi.org/10.4000/brussels.1316 
HLAVÁČEK P., RAŠKA P. \& BALEJ M. (2016), "Regeneration projects in Central and Eastern European post-communist cities: Current trends and community needs", Habitat International, 56, pp. 31-41, https://doi.org/10.1016/j.habitatint.2016.04.001

HONDAGNEU-SOTELO P., AVILA E. (1997), “'I'm Here, but I'm There', The Meanings of Latina Transnational Motherhood", Gender and Society, 11, 5, pp. 548-571, https://doi.org/10.2307/190339

HORVÁTH I. (2007), "Historical Trends in Emigration and Immigration. Aspects of migration before Communism”, Focus MIGRATION in Country Profile: Romania, Hamburg Institute of International Economics (HWWI).

IRIMIE R.C. (2014), "Daily Life Under Communism. The Case of Romania”, SEA - Practical Application of Science, 3, pp. 266-283.

KACZMARCZYK P., ANACKA M. \& FIHEL A. (2016), “Migration as an Asset? Polish Returnees at the Time of the Crisis", in KAHANEC M., ZIMMERMANN K.F., Labor Migration, Springer, pp. 219-246.

KAHANEC M., ZIMMERMANN K.F. (2016), Labor Migration, EU Enlargement, and the Great Recession, Berlin, Heidelberg, Springer.

LEUSTEAN L.N. (2007), “Constructing Communism in the Romanian People's Republic. Orthodoxy and State, 1948-49”, Europe-Asia Studies, 59, 2, pp. 303-329, https://doi.org/

$10.1080 / 09668130601127060$

LEWIS P. (1979), "Defining a sense of place”, Southern quarterly, 17, 3, pp. 24-46.

MAJURU A. (2019), De ce au construit comuniștii apartamentele faȚă-n faȚă și cum ne-a schimbat asta viaȚa. Matricea, https://matricea.ro/adrian-majuru-de-ce-au-construit-comunistiiapartamentele-fata-n-fata-si-cum-ne-a-schimbat-asta-viata/

MEEUS B. (2013), “Welfare through Migrant Work: What If the Romanian 'safety Valve' Closes?”, South-East Europe and the Black Sea Region, 13, 2, pp. 175-194, https://doi.org/

$10.1080 / 14683857.2013 .802177$

MOCANU M., BOLDUREANU G., TIȚĂ S.M. \& BOLDUREANU D. (2020), "The Impact of Migration on Quality of Life: The Case of Romanian Immigrants in Belgium”, Eastern European Economics, 58, 4, pp. 360-382, https://doi.org/10.1080/00128775.2020.1756336

NOWOK B., VAN HAM M., FINDLAY A.M. \& GAYLE V. (2013), “Does Migration Make You Happy? A Longitudinal Study of Internal Migration and Subjective Well-Being", Environment and Planning A: Economy and Space, 45, 4, pp. 986-1002, https://doi.org/10.1068/a45287

OECD (2019), Talent Abroad: A Review of Romanian Emigrants, OECD Publishing, Paris, https:// doi.org/10.1787/bac53150-en

PORTES A. (1997), “Globalization from Below: The Rise of Transnational Communities”, ESRC Transnational Communities Programme Working Paper, 1.

PORTES A., GUARNIZO L. \& LANDOLT P. (1999), Transnational communities, Routledge.

PRELIPCEANU R. (2008), “The new migration patterns of educated Romanians to the EU: what challenges for the individuals and for the nation-state?", Romanian Journal of European Affairs, 8, 4, https://ssrn.com/abstract=1299634

RELPH E. (1976), Place and placelessness, London, Pion.

SANDU D., TOTH G. \& TUDOR E. (2018), "The nexus of motivation-experience in the migration process of young Romanians", Population, Space and Place, 24, 1, e2114, https://doi.org/10.1002/ psp. 2114 
SCHMITZ S. (2012), « Un besoin de territoire à soi : quelques clés pour un aménagement des espaces commun », Belgeo, 1, https://journals.openedition.org/belgeo/6627

SÉCHET R., VASILCU D. (2015), "Physicians' migration from Romania to France: A brain drain into Europe?", Cybergeo: European Journal of Geography, 743, https://doi.org/10.4000/cybergeo.27249

SHAMAI S. (1991), "Sense of Place: An Empirical Measurement”, Geoforum, 22, pp. 347-358, https://doi.org/10.1016/0016-7185(91)90017-K

SHAMAI S., ILATOV Z. (2005), "Measuring Sense of Place: Methodological Aspects”, Tijdschrift voor Economische en Sociale Geografie, 96, pp. 467-476, https://doi.org/10.1111/j.1467-9663.2005.00479.x

STATBEL (2020), Population par commune selon la nationalité et le sexe depuis 1992.

STANISCIA B., BENASSI F. (2018), “Does regional development explain international youth mobility?", Belgeo, 3, https://doi.org/10.4000/belgeo.30305

TRANDAFOIU R. (2013), Diaspora Online: Identity Politics and Romanian Migrants, New York, Oxford, Berghahn Books.

YANG Z., CAI J., QI W., LIU S. \& DENG Y. (2017), “The Influence of Income, Lifestyle, and Green Spaces on Interregional Migration: Policy Implications for China", Population, Space and Place, 23, 2, e1996, https://doi.org/10.1002/psp.1996

WITCHALLS S. (2020) "A global view of design and urban planning post-COVID-19 (Part 4): How will cities change?", in Blog Post, https://www.stantec.com/en/ideas/topic/cities/a-global-viewof-design-and-urban-planning-post-covid-19-part-4-how-will-cities-change

\section{APPENDIXES}

\section{SCALE OF SENSE OF PLACE}

\begin{tabular}{l} 
0: No sense of place \\
\hline $\begin{array}{l}\text { The place is not recognized as such, it is not differentiated from neighboring places or larger } \\
\text { places. }\end{array}$ \\
\hline 0,5 \\
\hline $\begin{array}{l}\text { The place is known but not distinguished from the surrounding places, it is diffuse and poorly } \\
\text { located. }\end{array}$ \\
\hline 1: Recognition of the place \\
\hline $\begin{array}{l}\text { The place is distinguished from other places, but the inhabitant does not recognize a possible } \\
\text { influence of this place on his life. (Recognition) }\end{array}$ \\
\hline 1,5 \\
\hline The place is distinguished from other places, it has a certain interest (for example aesthetic) \\
\hline 2: Belong to the place
\end{tabular}


There is a sense of interdependence with the place. What happens at the place level is important because it has consequences for his life. (Respect)

\section{3: Attachment to a place}

There is an emotional attachment at the place level. It is the center of important personal experiences and it has personal meaning for the inhabitant. It is unique. (Attachment)

4: Merger with the purposes of the place

Fusion with the interests and needs of the place, devotion, loyalty towards the place. (Allegiance)

\section{5: Involvement in the place}

Active role, personal investment of resources. (Commitment)

6: Sacrifice for the place

Sacrifice of important elements. (Sacrifice)

(Schmitz, 2012)

\section{NOTES}

1. Data extracted from Statbel on May 26, 2020, referring to foreign nationals holding a residence permit in Brussels. See: "Population par commune selon la nationalité et le sexe depuis 1992".

2. We cannot talk about large-scale international migration from Romania before the fall of communism, given that citizens did not have the right to hold a permanent passport and those who received permission from the Communist Party to travel abroad were closely monitored and had to give up to their temporary passport when returning to the country. Very few dissidents managed to obtain political asylum, while most of those who tried to flee communist Romania were imprisoned or killed (Culic, 2005).

3. For more on the concept of transnational communities, see Portes, 1997 and Portes et al., 1999.

4. Belgian law offers the possibility to apply for citizenship after five years of uninterrupted residence. With the signing of the royal decree, even if they also retain the citizenship of his country of origin, the citizen is now considered Belgian. They disappear from the records of the residents and "migrates" into the statistics of naturalized citizens.

5. See Report from the Commission to the European Parliament and the Council pursuant to Article 27 of the Staff Regulations of Officials and to Article 12 of the Conditions of Employment of Other Servants of the European Union (Geographical balance) 2018.

6. See ANNEX 3: Methodology for the calculation of reference values and recruitment targets of new Member States from Report from the Commission to the European Parliament and the Council 2018.

7. See Annual Report on the human resources of the European Parliament - 2018, 4.5 Parliament Secretariat staff demographics in 2018.

8. See Annual Report on the human resources of the European Parliament - 2018, Annex 8a: Statistics of EPSO AD5 competitions (excluding linguists) over the period 2010-mid 2017.

9. For other examples of political transnational practices among other communities, see Ostergaard-Nielsen's 2001 study of Turks and Kurds in Germany and the Netherlands. 


\section{ABSTRACTS}

Focusing on a population of white-collar immigrants who chose to move from Romania to Brussels-Capital Region between 2014 and 2019, this article signals the formation of a third wave of Romanian migration. The participants in the study are Romanians residing in Brussels, corresponding to the features of the European Man (Homo Europaeus) and they belong to the "middle class" leaving Romania at an accelerated pace motivated by the desire to achieve a transnational lifestyle and an improvement of subjective well-being. We draw our findings from both quantitative data on mobility in the EU and qualitative research that reveals what are the elements that push, attract, and retain RWCIs to Brussels. It is also an opportunity to reflect upon the notion of sense of place experienced by a population that, despite having only recently moved to Brussels, already shows a high degree of attachment.

Depuis la fin des restrictions de mobilité intracommunautaire en 2014, la Région de BruxellesCapitale connaît une troisième vague de migration roumaine qui diffère des précédentes par sa composition socio-économique. La recherche investigue les motivations migratoires de ces Roumains issus de la «classe moyenne » récemment arrivés à Bruxelles. Ils sont de plus en plus nombreux à quitter la Roumanie motivés par la recherche d'une meilleure qualité de vie, qui outrepasse les seuls aspects financiers, tout en développant un mode de vie transnational, se rapprochant ainsi des caractéristiques de l'homme européen (Homo Europaeus). Nos conclusions reposent sur l'analyse de données quantitatives sur la mobilité dans l'UE et sur une recherche qualitative combinant une enquête en ligne et des entrevues avec ces nouveaux Bruxellois. A côté de la mise en évidence des facteurs qui poussent, attirent et retiennent ces nouveaux migrants à Bruxelles, l'étude constate un haut degré d'attachement à la capital belge et un désir de s'y investir durablement.

\section{INDEX}

Keywords: Romanian migration, Brussels, transnational lifestyle, white-collar, sense of place Mots-clés: migration roumaine, Bruxelles, mode de vie transnational, cols blancs, sens du lieu

\section{AUTHORS}

SANDA NICOLA

Laplec, UR SPHERES, Department of Geography, University of Liège, senicola@doct.uliege.be CAROLINE ZICKGRAF

HUGO, UR SPHERES, Department of Geography, University of Liège, Caroline.Zickgraf@uliege.be

\section{SERGE SCHMITZ}

Laplec, UR SPHERES, Department of Geography, University of Liège, S.Schmitz@uliege.be 